Brit. J. industr. Med., 1965, 22, 101.

\title{
BYSSINOSIS IN CARDROOM WORKERS IN SWEDISH COTTON MILLS*
}

\author{
BY \\ L. BELIN, A. BOUHUYS, $\uparrow$ W. HOEKSTRA, M.-B. JOHANSSON, \\ S.-E. LINDELL,+ and J. POOL \\ From the Departments of Allergology and Clinical Physiology, Sahlgrenska Sjukhuset, Gothenburg, Sweden, \\ and the Laboratory of Clinical Physiology, University Hospital, Leiden, The Netherlands
}

(RECEIVED FOR PUBLICATION OCTOBER 12, 1964)

The prevalence of byssinosis and chronic respiratory symptoms was studied in 117 workers in four Swedish cotton mills. Changes of forced expiratory volume in $0.75 \mathrm{sec}$. (F.E..$_{\cdot 0 \cdot 75}$ ) during a Monday and a Wednesday were assessed in 64 male workers in four cardrooms in these mills. Dust sampling was performed with weighed millipore filters.

Prevalences of byssinosis as judged from the workers' histories were $68 \%, 55 \%, 44 \%$, and $25 \%$ in the four mills; the lowest prevalence of $25 \%$ was found in a mill spinning both high grade cotton yarn and rayon. Among 67 workers in the mills having a byssinosis prevalence of $68 \%$ and $55 \%$, $60 \%$ were non-smokers, $70 \%$ had chronic cough, and $27 \%$ had chronic dyspnoea. The F.E.V $\cdot_{\cdot 0 \cdot 75}$ decreased on Monday in workers who gave a history of Monday dyspnoea, and to a lesser degree, but still significantly, in those who did not.

In spite of marked differences in fine dust (i.e., dust smaller than $2 \mathrm{~mm}$. diameter) concentrations in the four cardrooms, no significant relations between dust content, byssinosis prevalence, and F.E.V $\cdot_{\cdot 0 \cdot 75}$ changes on Monday could be demonstrated.

The prevention and treatment of byssinosis is discussed. Workers at risk should receive a periodical medical examination including at least a spirographical pulmonary function test at intervals of one year or less.

Individual cases of byssinosis have been diagnosed in Swedish cotton workers since 1960 (Arnoldsson, Bouhuys, and Lindell, 1963). Visits to a number of cotton mills in the Gothenburg area, and discussions with their managers, led to the impression that the prevalence of byssinosis was high enough to constitute a problem and a matter of concern to mill management. Some managers expressed the opinion that the prevalence of byssinosis had been increasing in recent years. The widespread use of mechanical cotton pickers, in particular in the United States, has led to increasing amounts of impurities in cotton received from overseas, in spite of attempts to clean cotton at the gins; and managers blamed these impurities for the increasing problem of byssinosis.

*This investigation was supported by grants from the Swedish Medical Research Council and the National Tuberculosis Association -American Thoracic Society.

†Present address: John B. Pierce Foundation Laboratory, New Haven, Conn., U.S.A.

†Present address: Department of Clinica Physiology, Malmö General Hospital, Malmö, Sweden.
However, an increase in byssinosis symptoms among workers may also result if the mill's production rate increases without a concomitant increase in the capacity of the available dust removal equipment (Bouhuys, 1963b).

To obtain information on the prevalence of byssinosis in Swedish cotton mills it was decided to conduct a field survey among cardroom workers in four different mills in the Gothenburg area. This study was performed in October 1962.

\section{Methods}

The study was performed in four different cotton mills (A, B, C, and D), all located near Gothenburg. A standard questionnaire was used to interview workers in all four mills; this included questions on present and past health, previous hospitalization and medical care, dyspnoea and tightness in the chest, wheezing, cough, sputum production, asthma, hay fever, and smoking habits. Additional questions 
tried to relate the occurrence of any respiratory symptoms to particular days of the week. The same person interviewed all the workers. In some cases, supplementary information was obtained at the time of the physiological tests. The following definitions were used in evaluating the workers' histories. Chronic cough was diagnosed when the question: 'Do you cough every day' was answered in the affirmative. Chronic dyspnoea was diagnosed when a positive answer was obtained to either one or both of two questions: 'Are you short of breath when you walk upstairs at normal speed?' and 'Are you short of breath when you walk on the level?' The characteristic symptom complex of byssinosis, summarized by the term 'Monday-dyspnoea', was diagnosed when dyspnoea, tightness, wheezing, and cough occurred only or predominantly on Monday. In all except three cases a combination of two or more of these symptoms was present. In three cases the history was considered positive because of persistent cough occurring only on Monday. The amounts of tobacco smoked were estimated in grams consumed per week. All workers actively employed at the time of investigation were interviewed. Three among these, in mills A and $B$, were absent because of illness when the function tests were performed two weeks later. In this study, all personnel who work in the room where the carding engines are installed have been termed 'card-room workers'. This group has been separated into two categories: 'carders', i.e., those whose work is at or close to the cards, and 'others', i.e., those who work at other machines in the same room, e.g., drawing and roving frame personnel.

Of the four mills studied, mill D was exceptional in that only high grade cotton yarns were produced, mainly from hand-picked first-grade Egyptian cotton. On some cards, rayon was being processed at the same time. The dust in this mill is therefore probably a mixture of cotton and rayon dust, although mainly the former. The other three mills produced mostly standard quality cotton yarns, but different qualities of cotton were in fact being processed at the time of this study.

To substantiate the data from the histories, lung function tests were performed in all available cardroom workers in four different cardrooms (No. 1 in mill A; Nos. 2, 3, and 4 in mill B). Cardrooms 1 and 2 were more than 20 years old. Cardroom 3 had been installed in 1957 in an old building, and No. 4 was installed in 1959 in a new building. Only the latter cardroom was provided with modern dust extraction equipment, which delivered a mixture of outside and recirculated air to the room. The recirculated air was obtained by suction under each card and passed through a filtering plant. Different types of ventilators and air filters were used in card- rooms 1,2 , and 3 , but in none of them was dust-laden air removed specifically at or close to the cards.

Changes of lung function during working days were assessed from the volume of air expired during the first $\mathbf{0 . 7 5}$ second of a forced expiration after a maximal inspiration (F.E.V..$_{0.75}$ ). A modified Gaensler spirometer was used for this function test. The test was performed on a Monday and a Wednesday, before the workers started work and at the end of their working day. Five measurements were made on each of these occasions, and the average of the two highest values among these five was taken as the result of the test, as in previous studies (Bouhuys, van Duyn, and van Lennep, 1961; Bouhuys, 1963a, $1963 b$ ). In all workers 50 years of age or older this test was supplemented by another set of F.E.V.0.75 measurements $5 \mathrm{~min}$. after inhalation of isoproterenol, a bronchodilating drug, using a 'Medihaler'. All results obtained in male cardroom workers, whether working at the cards or not, are reported in this paper. The results obtained in six female workers have been omitted in order not to complicate the analysis unduly.

Dust was sampled by drawing air at a constant flow rate, measured by dry test meter, usually for three hours or more, through weighed membrane filters (Type Millipore AA).* These filters had been dried for two hours at $70^{\circ} \mathrm{C}$. They were mounted in filter holders behind a metal screen with $2 \mathrm{~mm}$. wide openings. Another metal screen around the filter holder prevented sidewise access of dust to the filter. Filters were suspended at about breathing height with the air intake downward. Dust from the $2 \mathrm{~mm}$. metal screen was scraped off at regular intervals and weighed ('coarse dust' fraction). The dust collected on the filters has been termed 'fine dust' for the purpose of this study. This definition of 'fine dust' corresponds to the sum of medium (i.e., less than $2 \mathrm{~mm}$. but larger than $7 \mu$ diameter) and fine (i.e., smaller than $7 \mu$ diameter) dust in the methods used in Schilling's studies (Roach and Schilling, 1960). Dust was sampled at various sites in the cardrooms, but only results of samples taken between the carding engines are reported to facilitate comparisons between different cardrooms.

\section{Results}

The conditions in the four mills where histories of cardroom workers and estimations of airborne dust concentrations were obtained are summarized in Table 1. Concentrations of fine dust and byssinosis

*The dust measurements were performed by Mr. B. Jonsson, Ing. I. Skare, Ing. S. Skyllberg, and civ. Ing. P. Odelycke of the National Institute for Public Health, Stockholm, Sweden, to whom we are indebted for permission to include their findings in this report. 
prevalence, as judged from the histories, are similar in mills $\mathrm{A}, \mathrm{B}$, and $\mathrm{C}$, but in mill $\mathrm{D}$ the fine dust concentrations are lower and fewer workers complain of Monday dyspnoea.

Further data for the men in mills A and B (cardrooms $1,2,3$, and 4) are given in Tables 2 to 7 . The average age and the duration of employment differed only slightly between the groups in these four different cardrooms (Table 2). The percentage of workers with a history of dyspnoea on Monday varied from $50 \%$ to $100 \%$ in the four rooms, and this percentage has no obvious relation to the dustiness of the room. A large proportion of the workers were non-smokers and had never smoked; none smoked more than 20 cigarettes per day. Average cigarette consumption was low among all four groups. Among the carders, $55 \%$ were nonsmokers and among the others $56 \%$ (Table 3). It is the more striking that about $70 \%$ of all workers have a chronic cough, and $27 \%$ mention that they are regularly short of breath on exertion (Table 2 ).

A history of Monday dyspnoea is somewhat less common among those who do not work at the cards (Table 3). It is equally common among cigarette

TABLE 1

BYSSINOSIS IN FOUR COTTON MILLS

\begin{tabular}{|c|c|c|c|c|c|c|c|c|}
\hline Mill & $\begin{array}{l}\text { Fine Dust } \\
\left.\text { (mg./m. } .^{3}\right)\end{array}$ & $\begin{array}{l}\text { Coarse Dust } \\
\left(\mathrm{mg} . / \mathrm{m}^{3}\right)\end{array}$ & $\begin{array}{l}\text { No. of } \\
\text { Workers }\end{array}$ & $\begin{array}{c}\text { Duration of } \\
\text { Employment } \\
(\mathrm{yr} .)\end{array}$ & $\begin{array}{l}\text { No. of } \\
\text { Carders }\end{array}$ & $\underset{\substack{\text { With } \\
\text { Byssinosis } \dagger}}{\text { (\%) }}$ & $\begin{array}{l}\text { No. of } \\
\text { Others }\end{array}$ & $\underset{\substack{\text { With } \\
\text { Byssinosis }}}{\text { \% }}$ \\
\hline $\begin{array}{l}\mathbf{A} \\
\mathbf{B} \\
\mathbf{C} \\
\mathbf{D}\end{array}$ & $\begin{array}{l}3.64(9) \\
2.32(11) \\
4.54(16) \\
1.65(20)\end{array}$ & $\begin{array}{l}1 \cdot 10(8) \\
0.41(11) \\
2.17(15) \\
0.54(11)\end{array}$ & $\begin{array}{l}22 \\
45 \\
26 \\
24\end{array}$ & $\begin{array}{l}20 \cdot 7 \\
15 \cdot 8 \\
14 \cdot 5 \\
17 \cdot 1\end{array}$ & $\begin{array}{l}11 \\
26 \\
10 \\
16\end{array}$ & $\begin{array}{l}73 \\
77 \\
60 \\
31\end{array}$ & $\begin{array}{r}11 \\
19 \\
16 \\
8\end{array}$ & $\begin{array}{l}55 \\
68 \\
44 \\
25\end{array}$ \\
\hline
\end{tabular}

Dust concentrations: figures in parentheses are nos. of samples.

*'Others' are all workers in the cardroom who do not work at the cards, e.g., drawing and roving frame personnel.

†Percentage of workers with history of Monday dyspnoea.

TABLE 2

HISTORIES OF CARDROOM WORKERS IN MILL A (CARDROOM 1) AND MILL B (CARDROOMS 2, 3, AND 4)

\begin{tabular}{|c|c|c|c|c|c|c|c|c|c|c|}
\hline Cardroom & $\begin{array}{l}\text { No. of } \\
\text { Workers }\end{array}$ & $\begin{array}{l}\text { Age } \\
\text { (yr.) }\end{array}$ & $\begin{array}{c}\text { Exposed } \\
\text { (yr.) }\end{array}$ & $\begin{array}{c}\text { Monday } \\
\text { Dyspnoea } \\
(\%)\end{array}$ & $\begin{array}{c}\text { Chronic } \\
\text { Cough } \\
(\%)\end{array}$ & $\mid \begin{array}{c}\text { Chronic } \\
\text { Dyspnoea } \\
(\%)\end{array}$ & $\begin{array}{c}\text { Non- } \\
\text { smokers } \dagger \\
(\%)\end{array}$ & $\begin{array}{c}\text { Cigarette } \\
\text { Smoking } \\
\text { (g./wk) }\end{array}$ & $\begin{array}{l}\text { Fine Dust } \\
\text { (mg./m. }{ }^{3} \text { ) }\end{array}$ & $\begin{array}{c}\text { Coarse Dust } \\
\left(\mathrm{mg} . / \mathrm{m} .^{3}\right)\end{array}$ \\
\hline $\begin{array}{l}1 \\
2 \\
3 \\
4\end{array}$ & $\begin{array}{l}22 \\
15 \\
12 \\
18\end{array}$ & $\begin{array}{l}48 \cdot 8 \\
49 \cdot 4 \\
49 \cdot 3 \\
44 \cdot 5\end{array}$ & $\begin{array}{l}20 \cdot 7 \\
15 \cdot 7 \\
16 \cdot 7 \\
15 \cdot 2\end{array}$ & $\begin{array}{r}63.6 \\
80.0 \\
100.0 \\
50.0\end{array}$ & $\begin{array}{l}72 \cdot 7 \\
86 \cdot 7 \\
83 \cdot 3 \\
44 \cdot 4\end{array}$ & $\begin{array}{l}31 \cdot 8 \\
13 \cdot 3 \\
33 \cdot 3 \\
27 \cdot 8\end{array}$ & $\begin{array}{l}54.5(31 \cdot 8) \\
73.3(73 \cdot 3) \\
41.7(41 \cdot 7) \\
66.7(55.6)\end{array}$ & $\begin{array}{l}60 \cdot 2(10) \\
62 \cdot 5 \quad(4) \\
40 \cdot 0 \quad(7) \\
53 \cdot 3 \quad(6)\end{array}$ & $\begin{array}{l}3.64 \text { (9) } \\
4.02 \text { (5) } \\
1.73 \text { (10) } \\
1.87 \text { (10) }\end{array}$ & $\begin{array}{ll}1 \cdot 10 & (8) \\
0 \cdot 50 & (4) \\
0 \cdot 30 & (5) \\
0 \cdot 30 & (5)\end{array}$ \\
\hline Total & 67 & 47.9 & $17 \cdot 4$ & $70 \cdot 1$ & $70 \cdot 1$ & 26.9 & $59 \cdot 7(49 \cdot 3)$ & $53.8(27)$ & $2 \cdot 61$ & 0.63 \\
\hline
\end{tabular}

*No. of years workers spent in cardrooms.

$\dagger$ Percentage of persons who did not smoke cigarettes at time of study. Figures in parentheses are percentages of persons who never used tobacco in any form.

‡Amount of cigarette tobacco consumed by cigarette smokers (no. of cigarette smokers in parentheses).

Columns 10 and 11: No. of sample locations in parentheses.

TABLE 3

HISTORY OF BYSSINOSIS AND CHRONIC COUGH RELATED TO JOB AND SMOKING HABITS

\begin{tabular}{|c|c|c|c|c|c|c|c|c|c|}
\hline & \multicolumn{3}{|c|}{ Carders } & \multicolumn{3}{|c|}{ Others } & \multirow{2}{*}{$\underset{\text { Smokers }}{\text { All }}$} & \multirow{2}{*}{$\begin{array}{l}\text { All Non- } \\
\text { smokers }\end{array}$} & \multirow[b]{2}{*}{ Total } \\
\hline & Smokers & $\begin{array}{c}\text { Non- } \\
\text { smokers }\end{array}$ & Total & Smokers & $\begin{array}{c}\text { Non- } \\
\text { smokers }\end{array}$ & Total & & & \\
\hline \multirow{3}{*}{$\begin{array}{l}\text { No. of } \\
\text { workers } \\
\text { History of } \\
\text { byssinosis } \\
\text { Chronic } \\
\text { cough }\end{array}$} & 15 & 18 & 33 & 12 & 15 & 27 & 27 & 33 & 60 \\
\hline & $12(80)$ & $15(83)$ & $27(82)$ & $7(58)$ & $9(60)$ & $16(59)$ & $19(70)$ & $24(73)$ & $43(72)$ \\
\hline & $12(80)$ & $12(67)$ & $24(73)$ & $9(75)$ & $9(60)$ & $18(67)$ & $21(78)$ & $21(64)$ & $42(70)$ \\
\hline Both & $9(60)$ & $11(61)$ & $20(61)$ & $7(58)$ & $6(40)$ & $13(48)$ & $16(59)$ & $17(52)$ & $33(55)$ \\
\hline Neither & $0 \quad(0)$ & $2(11)$ & $2(6)$ & $3(25)$ & $3(20)$ & $6(22)$ & $3(11)$ & $5(15)$ & $8(13)$ \\
\hline
\end{tabular}

The table shows the number of workers in each category who have a history of byssinosis, a history of chronic cough, a history of both, or of neither. Percentages in each group are in parentheses. The total number of workers is smaller than in Table 2 because seven ex-smokers, cıgar and pipe smokers have been excluded from this analysis. For definition of 'carders' and 'others' see Methods. 
smokers and among persons who never smoked at all; this applies both to carders and to others (Table 3). Chronic cough is slightly more common among cigarette smokers than among non-smokers, and also more common among carders than among others (Table 3). However, the number of workers in each group is small and the difference between smokers and non-smokers, and that between carders and others is not significant (chi-square test).

The increase in the incidence of chronic cough with age (Table 4) is significant when the 16-34 year age group is compared with the $55+$ group (chisquare test). The difference between 23 workers exposed for less than 10 years $(65.2 \%$ incidence of chronic cough) and 15 workers exposed for 30 years or more $(86.7 \%)$ is suggestive but not significant at the $5 \%$ level. Apparently the material is too small to discriminate between the eventual effects of age and of industrial exposure on the incidence of chronic cough.

A significant decrease of F.E.V $\cdot_{\cdot 0 \cdot 75}$ on Monday occurred both in those who gave a history of Monday dyspnoea and in those who did not (Table 5). However, the decrease was smaller in the latter group. Smaller F.E.V $\cdot_{0 \cdot 75}$ changes were observed on Wednesday, and these were insignificant in those who gave no history of Monday dyspnoea. The Figure illustrates the distribution of changes in F.E.V.0.75 among all workers on both Monday and Wednesday.

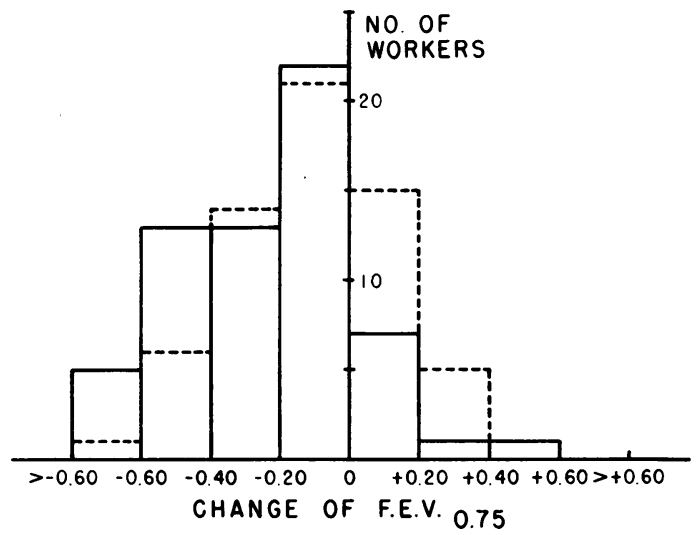

FIGURE.-Distribution of F.E.V.0.25 changes, in litres B.T.P.S., on Monday (continuous lines) and Wednesday (dotted lines) in cardroom workers.

TABLE 4

CHRONIC COUGH RELATED TO AGE, JOB, AND SMOKING HABITS

\begin{tabular}{|c|c|c|c|c|c|c|}
\hline & \multicolumn{5}{|c|}{ Age Group } & \multirow{2}{*}{$\begin{array}{c}\text { Chronic } \\
\text { Cough } \\
(\%)\end{array}$} \\
\hline & $16-34$ & $35-44$ & $45-54$ & $55+$ & Total & \\
\hline $\begin{array}{l}\text { Non-cigarette smokers } \\
\text { Cigarette smokers } \\
\text { Carders } \\
\text { Others }\end{array}$ & $\begin{array}{ll}6 & (2) \\
3 & (1) \\
2 & (1) \\
7 & (2)\end{array}$ & $\begin{array}{ll}7 & (4) \\
4 & (2) \\
7 & (4) \\
4 & (2)\end{array}$ & $\begin{array}{l}10(6) \\
12(11) \\
11(9) \\
11 \quad(8)\end{array}$ & $\begin{array}{r}17(14) \\
8(7) \\
17(13) \\
8(8)\end{array}$ & $\begin{array}{l}40(26) \\
27(21) \\
37(27) \\
30(20)\end{array}$ & $\begin{array}{l}65 \cdot 0 \\
77 \cdot 8 \\
73 \cdot 0 \\
66 \cdot 7\end{array}$ \\
\hline $\begin{array}{l}\text { Total } \\
\text { Chronic cough }(\%)\end{array}$ & $3_{3 \cdot 3}^{9.3)}$ & $\operatorname{l1}_{54 \cdot 5}^{(6)}$ & $\begin{array}{l}22(17) \\
77 \cdot 3\end{array}$ & $\begin{array}{l}25(21) \\
84.0\end{array}$ & $\begin{array}{l}67(47) \\
70 \cdot 1\end{array}$ & $70 \cdot 1$ \\
\hline
\end{tabular}

Columns $\mathbf{2}$ to $\mathbf{6}$ show the no. of persons in each category, with no. of persons with history of chronic cough in parentheses.

TABLE 5

CHANGES OF F.E.V.0.75 ON MONDAY AND WEDNESDAY

\begin{tabular}{|c|c|c|c|c|c|c|c|c|c|c|}
\hline & \multicolumn{5}{|c|}{ Monday } & \multicolumn{5}{|c|}{ Wednesday } \\
\hline & $\mathbf{A}$ & B & d & $\mathbf{t}$ & $\mathbf{P}$ & $\mathbf{A}$ & B & d & $\mathrm{t}$ & $\mathbf{P}$ \\
\hline History of byssinosis & 2.98 & $2 \cdot 72$ & $-0 \cdot 26$ & 6.667 & $<0.001$ & 2.93 & $2 \cdot 81$ & $-0 \cdot 12$ & $3 \cdot 750$ & $<0.001$ \\
\hline $\begin{array}{l}\text { No history of byssinosis } \\
(n=18)\end{array}$ & 3.41 & $3 \cdot 23$ & $-0 \cdot 18$ & $2 \cdot 744$ & $<0.02$ & $3 \cdot 32$ & $3 \cdot 22$ & $-0 \cdot 10$ & $1 \cdot 570$ & N.S. \\
\hline $\begin{array}{l}\text { Total group } \\
(\mathrm{n}=64)\end{array}$ & $3 \cdot 10$ & $2 \cdot 86$ & -0.24 & $7 \cdot 164$ & $<0.001$ & 3.04 & 2.92 & -0.12 & $4 \cdot 167$ & $<0.001$ \\
\hline
\end{tabular}

F.E.V.0.75 values are given in litres, B.T.P.S.

n $=$ no. of workers.

A = values before start of work.

B = values at end of work (about $8 \mathrm{hr}$. exposure).

d $=$ difference between columns $\mathbf{A}$ and $\mathbf{B}$.

$t \quad=$ Fisher's ' $t$ ' for paired variates.

$\mathbf{P}=$ probability that ' $t$ ' values arose by chance.

N.S. = not significant.

The small but systematic difference between starting values on Monday and Wednesday (coinpare values in the two columns A) is significant in the total group $(P<0.02)$ but not in the two subgroups. 
TABLE 6

CHANGES OF F.E.V. . .75 , BYSSINOSIS PREVALENCE, AND DUST LEVELS IN FOUR CARDROOMS

\begin{tabular}{|c|c|c|c|c|c|c|c|}
\hline \multirow[b]{2}{*}{ Cardroom } & \multirow{2}{*}{$\begin{array}{l}\text { No. of } \\
\text { Workers }\end{array}$} & \multirow{2}{*}{$\begin{array}{c}\text { Average F.E.V.0.75 } \\
\text { Decrease } \\
\text { (1. B.T.P.S.) }\end{array}$} & \multicolumn{3}{|c|}{ Prevalence of Byssinosis ( $\%)$} & \multirow{2}{*}{$\begin{array}{l}\text { Fine Dust } \\
\left(\mathrm{mg} \cdot / \mathrm{m} .^{3}\right)\end{array}$} & \multirow{2}{*}{$\underset{\left(\mathrm{mg} \cdot / \mathrm{m} .^{3}\right)}{\text { Coarse Dust }}$} \\
\hline & & & $\begin{array}{l}\text { Criterion } \\
\text { (1) }\end{array}$ & $\begin{array}{l}\text { Criterion } \\
\text { (2) }\end{array}$ & $\begin{array}{l}\text { Criterion } \\
\text { (1) }+ \text { (2) }\end{array}$ & & \\
\hline $\begin{array}{l}1 \\
2 \\
3 \\
4\end{array}$ & $\begin{array}{l}22 \\
15 \\
12 \\
15\end{array}$ & $\begin{array}{l}-0.14(<0.05) \\
-0.31(<0.001) \\
-0.29(<0.01) \\
-0.30(<0.01)\end{array}$ & $\begin{array}{l}41 \\
57 \\
58 \\
57\end{array}$ & $\begin{array}{r}64 \\
80 \\
100 \\
57\end{array}$ & $\begin{array}{r}77 \\
93 \\
100 \\
80\end{array}$ & $\begin{array}{l}3.64(9) \\
4.02(5) \\
1.73(10) \\
1.87(10)\end{array}$ & $\begin{array}{ll}1 \cdot 10 & (8) \\
0 \cdot 50 & (4) \\
0 \cdot 30 & (5) \\
0 \cdot 30 & (5)\end{array}$ \\
\hline Total & 64 & $-0 \cdot 24$ & 50 & 72 & 86 & & \\
\hline
\end{tabular}

Column 3: Average decrease of F.E.V.0.75 on Monday; value of $P$ in parentheses.

Criteria for diagnosis: (1) Decrease of F.E.V.0.7s on Monday equal to or larger than 0.2 litre B.T.P.S. (2) History of Monday dyspnoea.

Columns 7 and 8: Figures in parentheses are nos. of samples. 'Fine dust' is defined as dust with a particle diameter of less than 2 mm.; 'coarse dust' is dust with a particle diameter of $2 \mathrm{~mm}$. or more (see Methods).

Table 6 relates these changes of F.E.V.0.75 location and to the prevalence of byssinosis in four cardrooms. The difference between the F.E.V. $\cdot_{0 \cdot 75}$ changes in different cardrooms is not significant by Fisher's ' $t$ ' test for unpaired variates. Also the difference between the F.E.V $\cdot_{0 \cdot 75}$ decrease on Monday in workers in the two older cardrooms (1 and 2) and in those in the two newer cardrooms ( 3 and 4 ) is not statistically significant. The average decrease of F.E.V $\cdot_{0 \cdot 75}$ was greater among the carders $(-0.3101$ in 20 carders) than in workers performing other jobs in the cardrooms, but these differences again were not significant. Because byssinosis is characterized by dyspnoea primarily on the first working day of the week and less on other weekdays, the significance of the differences between the ventilation changes on Monday and Wednesday was also investigated. The decrease of F.E.V. $\cdot_{0 \cdot 75}$ on Monday was significantly larger, at the $1 \%$ level, than that occurring on Wednesday in the group with a history of Monday dyspnoea but not in those who denied having dyspnoea on Mondays.

The differences between carders and others who work in the cardroom (Tables 1, 3, and 4) cannot be explained by differences in the duration of employment among these two groups. On average, the carders had been employed $15 \cdot 3$ years (S.D. 12.3 years) and the others 19.9 years (S.D. 14.2). This difference is not significant (Fisher's ' $t$ ' test for unpaired variates).

The prevalence of byssinosis may be judged either from the worker's history or from changes in lung function tests, such as the F.E.V. $\cdot_{0 \cdot 75}$ or from both. Table 6 shows that the prevalence of byssinosis in all four cardrooms is high, and not obviously related to dust levels as measured in this study, whichever criterion is used. Criterion (1) is a decrease of F.E.V. $\cdot_{0 \cdot 75}$ on Monday of 0.2 litre or more. Criterion (2) is a history of Monday dyspnoea.

Criterion (1) includes persons who did not give a history of Monday dyspnoea but had a substantial
F.E.V.0.75 decrease on Monday; the number of such persons is indicated by the difference between prevalence as judged by criterion (2) and by criterion (1) + (2). On the other hand, these data also show that some workers give a history of Monday dyspnoea but do not show a substantial decrease of F.E.V.0.75 on Monday. The number of these is found from the difference between the prevalence of byssinosis as judged by criterion (1) and (2), respectively.

From the results of the dust measurements and the study of individual jobs, 38 workers were assigned arbitrary numbers from 0 to 5 to grade their relative exposure to dust. This was done by someone (Ing. I. Skare) who was not acquainted with the workers' histories or the results of the F.E.V. tests. Although the decrease of F.E.V. $\cdot_{0.75}$ on Monday appears to be larger in workers considered to be exposed to larger amounts of dust than in others, the positive correlation between these data (i.e., between the decrease of F.E.V.0.75 on Monday and the figure for dust exposure) is not significant $(r=+0.269 ; t=1.676$; Table 7).

TABLE 7

F.E.V.0.75 CHANGES ON MONDAY RELATED TO DUST

\begin{tabular}{c|c|c}
\hline $\begin{array}{c}\text { Dust } \\
\text { Exposure* }\end{array}$ & No. of Workers & $\begin{array}{c}\text { F.E.V. } 0.75 \\
\text { Decrease }\end{array}$ \\
\hline $0-0.9$ & 10 & $-0 \cdot 187$ \\
$1 \cdot 0-1.9$ & 12 & $-0 \cdot 288$ \\
$2 \cdot 0-9.9$ & 10 & $-0 \cdot 342$ \\
$3 \cdot 0-5 \cdot 0$ & 6 & $-0 \cdot 323$ \\
\hline
\end{tabular}

*Values indicate arbitrary comparative figures for dust exposure of each individual (see text).

$\dagger$ † verage decrease of F.E.V.0.7s on Monday, in litres B.T.P.S.

The long-term effect of exposure to cardroom dust was investigated by comparing the F.E.V.0.75/body height ratios in 15 byssinotic cardroom workers aged 55 to 67 years, who had been exposed to cotton dust for over 10 years, with similar data obtained from 
13 non dust exposed control subjects (prisoners and prison personnel) aged 55 to 65 years. The control data were taken from a previous study in which the same methods were used (Bouhuys, 1963a). Although the byssinotic subjects smoked considerably less than the control subjects, their F.E.V.0.75 $/$ body height ratio was $13.93 \mathrm{ml}$. B.T.P.S./cm. as compared with $17 \cdot 18 \mathrm{ml} . / \mathrm{cm}$. in the control subjects. This difference was significant at the $5 \%$ level $(t=2 \cdot 131)$. Five of these 15 workers had an F.E.V.0.75 of less than 2 litres $(6 \cdot 0-10 \cdot 3 \mathrm{ml} . / \mathrm{cm}$.) and were judged to have severe and partly irreversible ventilatory insufficiency. The F.E.V $\cdot_{0 \cdot 75}$ values of the cardroom workers used in this comparison were the highest observed in each individual. Usually these were the values obtained on Monday before the start of work, but values obtained after the inhalation of isoproterenol were used whenever these were the highest.

It is often believed that byssinosis develops only after several years of exposure to dust in cardrooms. In this connexion it is of interest that the group of workers in this study included six individuals who had been exposed to dust in a cardroom for only one year or less. Only one of them had a history of Monday dyspnoea, but all five others had an F.E.V.0.75 decrease on Monday of 0.2 litre or more. In three of these, who were foreign workers recently migrated to Sweden, lack of communication due to their incomplete understanding of the Swedish language may have been responsible for the negative history.

In many workers, the decrease of F.E.V. $\cdot_{0 \cdot 75}$ in the course of the working day on Monday was partially or completely reversed by isoproterenol inhalation, as in previous studies (Bouhuys et al., 1961; Bouhuys, 1963b). This was also true in older workers. In 28 workers 50 years or older, the F.E.V. .0 .75 was on average 2.7 litres on Monday morning, 2.36 litres at the end of Monday, and 2.58 litres after isoproterenol inhalation at the end of Monday. The latter value is significantly higher than the lowest value on Monday, but is still significantly lower than the starting value on Monday.

\section{Discussion}

The findings in the present investigation indicate that byssinosis occurs in these Swedish cotton mills in about the same percentage of cardroom workers as was found previously in similar workers in other countries (Schilling, 1956). However, our byssinosis prevalence rates are considerably higher than those recently reported by Lammers, Schilling, Walford, Meadows, Roach, van den Hoven van Genderen, van der Veen, and Wood (1964) in English and
Dutch mills spinning medium quality cotton yarns. The crude prevalence rates were $13.5 \%$ in the English and $17.0 \%$ in the Dutch mills (compare Table 3). The total dust concentrations in the English and Dutch mills $\left(2.9\right.$ and $1.9 \mathrm{mg} . / \mathrm{m}^{3}$, respectively) were lower than those in our cardrooms 1 and 2 but similar to those in cardrooms 3 and 4 (compare Table 2). In our study, however, the prevalence of byssinosis and of chronic respiratory symptoms in these four cardrooms did not differ significantly. Lammers et al. diagnosed byssinosis on its history only, which may explain part of the difference (compare Table 6), but this is very probably not the whole explanation. The prevalence of chronic respiratory symptoms in our subjects was also considerably higher than in those of Lammers et al., although the latter group included a higher percentage of cigarette smokers. The studies may not be comparable for other, not immediately obvious reasons, but it seems likely that technical differences between the mills studied, such as the quality of cotton processed, may be involved.

The decrease of F.E.V $\cdot_{\cdot 0 \cdot 75}$ during the first working day after the weekend break is similar to the decrease found by Batawi, Schilling, Valić, and Walford (1964). As Bates and Christie (1964) have recently discussed, it is of considerable interest that definite sensations of dyspnoea are associated with F.E.V. decreases in the order of only about $10 \%$.

The present data support the conclusion from other studies (Bouhuys, 1963a), i.e., that long-term exposure to cotton dust in byssinotic workers promotes the development of irreversible ventilatory insufficiency. The histories of the workers suggest a high prevalence of chronic respiratory complaints, apart from the typical syndrome of Monday dyspnoea in these workers. The moderate smoking habits in the group, and the large percentage of nonsmokers, indicate that smoking cannot be considered a major factor causing these complaints. Ferris, Anderson, and Burgess (1962) have stressed that studies of the effects of industrial air pollution should be performed as much as possible in groups of non-smoking subjects. The present study partly fulfils this requirement, to the extent that more than half of the subjects were non-smokers. Byssinotic workers usually state that smoking a cigarette on Monday will aggravate their Monday dyspnoea considerably. This is possibly the result of superimposition of the effect of one known bronchoconstrictor agent (i.e., tobacco smoke; Nadel and Comroe, 1961) on the effect of another such agent, i.e., cotton dust. This phenomenon may discourage the workers from smoking at all, but only two workers gave this as a reason for giving up smoking cigarettes. 
The data in Table 3 suggest that the prevalence of Monday dyspnoea is independent of smoking habits. Within the two groups (carders and others) a history of byssinosis was equally common among smokers and non-smokers. On the other hand, in each of these groups chronic cough occurred more often in smokers than in the non-smokers. However, the prevalence of chronic cough was high in all groups, and the differences were statistically not significant.

Although general hygienic and dust control measures in cardrooms 3 and 4 were better than those in cardrooms 1 and 2, an impression which was confirmed by dust concentration measurements (Table 2), it was impossible to demonstrate any significant difference between the prevalence of byssinosis or its severity in the workers in these different cardrooms. This comparison has been made between groups consisting of different individuals, and one should bear in mind the possibility that these groups may not be strictly compared for some other reason. Unfortunately, it was impossible, for technical reasons, to investigate the same individuals first in one cardroom and later in another. In this way each worker would have served as his own control, which would have been more satisfactory from a statistical point of view. The present results suggest, however, that the dust content differences between the cardrooms were not a major factor affecting the prevalence of byssinosis and the extent of the ventilatory changes on Monday in the workers.

Another attempt to relate ventilatory function changes in byssinosis to dust exposure is shown in Table 7. The workers considered to be more exposed to dust than others had, on average, a larger decrease of F.E.V. ${ }_{\cdot 0 \cdot 75}$ on Monday. However, the correlation between the figures for dust exposure, which took into account each worker's location in relation to the carding engines, and the F.E.V ${ }_{\mathbf{0}_{0 \cdot 75}}$ changes is weak and statistically not significant. This is in keeping with the finding that byssinosis is about equally prevalent in the better ventilated cardrooms 3 and 4 and in the less well equipped cardrooms 1 and 2, at least to the extent measurable by the methods used in the present study. Cardroom 4 had only been in use for three years, and one might suppose that the byssinotic workers in this room were affected because of previous employment in a more dusty atmosphere. However, it is well known that Monday dyspnoea in byssinosis is abolished soon after the worker is relocated to work in a non-dusty atmosphere, or an atmosphere containing 'non-byssinogenetic' dust such as rayon dust or dust of chemically degummed flax (Bouhuys, Hartogensis, and Korfage, 1963).

Byssinosis is now recognized as a serious and eventually disabling disease. If adequate removal of all dust from the atmosphere in the work areas is impossible to accomplish at the present time, other methods of preventing byssinosis have to be considered. Adequate pre-employment medical examinations might be helpful in eliminating individuals prone to develop chronic respiratory disease, such as patients with bronchial asthma, from the cardrooms. This category is, however, only a small minority among the working population. In the present study, only four workers had a personal history of bronchial asthma or hay fever. Further automation of carding procedures might reduce the number of workers at risk, and more efficient means of cleaning the cards might eliminate the need for manual cleaning. Electrostatic precipitation naturally suggested itself as a possible method of removing the fine dust from the atmosphere. As discussed at a recent symposium on byssinosis in Manchester (September, 1962), trials with this method have been made in Great Britain, so far, however, without encouraging results. This was mainly because of the need for very frequent cleaning of the precipitator. This difficulty may be obviated by the use of an automatic cleaning device now being developed in the United States of America.

Another approach to the prevention of byssinosis might be to remove the noxious agent from the dust. It seems probable that the causative agent in the dust resides in impurities and not in the cellulose fibres of cotton themselves. Measures to remove these impurities from the cotton might be easier and less costly than the installation of the certainly very expensive equipment for electrostatic precipitation of dust. If successful it would not only protect cardroom workers but also workers exposed to the risk of byssinosis during subsequent operations such as weaving of unsized yarns (Bouhuys, 1963b). Apart from the medical advantages, the removal of impurities from cotton would probably be of importance from a technical and economical point of view as well.

The inhalation of isoproterenol relieves Monday dyspnoea in many byssinotic workers; it can be prescribed by a physician in the form of convenient pocket inhalers. The workers should be properly instructed in the use of these instruments, and to avoid abuse refills should also be prescribed by a physician. Although an antihistamine drug (methydilazine hydrochloride; 'Tacaryl') has been shown to prevent ventilation changes on Monday in byssinotic workers when given before the start of work (Bouhuys, 1963c), this drug affords little subjective relief. It seems inadvisable at present to prescribe such a drug to byssinotic workers unless regular medical supervision is feasible. It seems reasonable 
to expect that relief of Monday dyspnoea by regular isoproterenol inhalation may prevent the development of irreversible lung function changes in the long run. However, a prolonged follow-up study would be needed to establish this as a fact, and no such studies are under way at present. Therefore, medical measures have a limited place in the prevention and treatment of byssinosis, and they should not detract from the prime necessity of preventing the inhalation of the noxious agents in cotton dust by the workers. As long as this has not been achieved, the workers at risk should receive regular medical attention at intervals of one year or less. In our view, these periodical examinations should include a spirographical lung function test such as the F.E.V.0.75 used in this study.

\section{REFERENCES}

Arnoldsson, H., Bouhuys, A., and Lindell, S.-E. (1963). Acta med. scand., 173, 761.

Batawi, M. A. El, Schilling, R. S. F, Valić, F., and Walford, J. (1964). Brit. J. industr. Med., 2i, 13.

Bates, D. V., and Christie, R. V. (1964). Respiratory Function in Disease, p. 474. Philadelphia and London, Saunders.

Bouhuys, A. (1963a). Amer, Rev, resp. Dis, 87, 63.

(1963b). Arch. environm. Hlth, 6, 465.

- (1963c). Clin. Pharmacol. Therap., 4, 311.

-, van Duyn, C., and van Lennep, H. J. (1961). Arch. environm. Hlth, 3, 499.

-, Hartogensis, F., and Korfage, H. J. H. (1963). Brit. J. industr. Med., 20, 320 .

Ferris, B. G., Anderson, D. O., and Burgess, W. A. (1962). Ibid., 19,180 .

Lammers, B., Schilling, R. S. F., Walford, J., Meadows, S., Roach, S. A., van den Hoven van Genderen, D., van der Veen, Y. G., and Wood, C. H. (1964). Ibid., 21, 124 .

Nadel, J. A., and Comroe, J. H., Jr. (1961). J. appl. Physiol., 16, 713. Roach, S. A., and Schilling, R. S. F. (1960). Brit. J. industr. Med. 17,1 .

Schilling, R. S. F. (1956). Lancet, 2, 261, 319. 